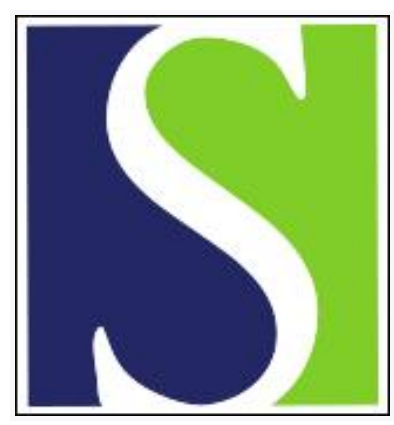

Scand J Work Environ Health 2000;26(2):99-105

https://doi.org/10.5271/sjweh.518

Issue date: Apr 2000

Cancer incidence among male pulp and paper workers in Norway

by Langseth $\mathrm{H}$, Andersen A

The following article refers to this text: 2004;30(5):356-361

Key terms: lung cancer; malignant melanoma; occupational cohort; pleural mesothelioma; pulp and paper mill

This article in PubMed: www.ncbi.nlm.nih.gov/pubmed/10817374

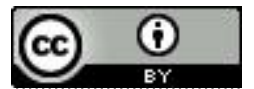




\title{
Cancer incidence among male pulp and paper workers in Norway
}

\author{
by Hilde Langseth, MSc, ${ }^{1}$ Aage Andersen ${ }^{1}$
}

\author{
Langseth $\mathrm{H}$, Andersen $\mathrm{A}$. Cancer incidence among male pulp and paper workers in Norway. Scand $J$ Work Environ \\ Health 2000;26(2):99-105.
}

Objectives The study investigated cancer incidence among 23718 male pulp and paper workers employed continuously for at least 1 year between 1920 and 1993 in Norway.

Methods The name, date of birth, personal identification number, dates of hire and termination for all employment periods, specific department, and job categories were registered for each worker. Six subcohorts were established (sulfite mill, sulfate mill, paper mill, maintenance department, administrative staff and other departments). Data on the cohort were linked with data in the Norwegian Cancer Register. The follow-up period for cancer incidence, date of death, or emigration was from 1953 through 1993.

Results An excess incidence of lung cancer was found among both short- and long-term employees [standardized incidence ratio (SIR) $1.5,95 \%$ confidence interval $(95 \% \mathrm{CI}$ ) $1.13-2.03$ and SIR $1.2,95 \% \mathrm{CI} 1.09-1.34$, respectively], especially for workers with the longest latency (SIR 1.3,95\% CI 1.08-1.44) and for sulfite mill workers (SIR 1.5, 95\% CI 1.09-1.99). The risk for pleural mesothelioma was also increased (SIR 2.4, 95\% CI $1.45-3.75$ ), especially among maintenance workers. The results also showed an increased risk for malignant melanoma (SIR 1.3, 95\% CI 1.04-1.60), an unexpected finding.

Conclusions Almost all the increased risk for lung cancer can be explained by a combination of smoking habits and asbestos use, although an effect of other work-related exposures (sulfur and chloride compounds, wood dust) cannot be excluded. Most of the cases of pleural mesothelioma occurred in departments where asbestos was used. There is no clear explanation for the excess of malignant melanoma, and the finding may be a chance occurrence.

Key terms lung cancer, malignant melanoma, occupational cohort, pleural mesothelioma, pulp and paper mills.

The first chemical cellulose mill in Norway opened in 1870 , and the processing of paper started in 1890. Pulp and paper have traditionally been produced by 1 of 2 chemical processes, sulfite (acidic) and sulfate (alkaline), and by 1 mechanical process. The main potential exposures are to gaseous sulfur compounds (sulfur dioxide, hydrogen sulfide, organic sulfides, mercaptans), chlorine, and chlorine compounds. Established carcinogens such as asbestos, wood dust, and formaldehyde have all been common in these workplaces. Various other biologically active substances, such as paper dust, polychlorinated biphenyls (PCBs), dyes (auramine and other benzidinebased), resins, microbes and talc, have also been identified in the work atmosphere.

The health effects of work in the pulp and paper industry have been reviewed (1), and excess incidences of lung cancer, malignant mesothelioma, and malignant lymphomas have been associated with these occupational exposures. Few studies have reported increased can- cer risks among female workers in pulp and paper mills, except for an increased risk for ovarian cancer in a Norwegian study (2). Increased incidences of lung cancer have been observed among sulfite mill workers $(3,4)$, sulfate mill workers (5), workers exposed to organic chlorinated compounds (6), and paper and board mill workers (7). Furthermore, an excess risk for lung cancer was observed for maintenance workers; it was attributed to exposure to asbestos (8) and to wood dust (9). Other investigators, however, found no increase in lung cancer risk for pulp and paper workers (10-14).

Asbestos was used widely as an insulating material in process equipment such as boilers and in the brakes of slitter-winders and other rolling machines; this use has been associated with the excess risk for pleural mesothelioma observed among pulp and paper workers $(15,16)$.

Sulfite mill workers (17) and pulp mill workers (18) have been found to have an increased risk for lymphosarcoma and reticulum-cell sarcoma. Both pulp and paper 
workers were also reported to have increased risks for Hodgkin disease, multiple myeloma (19), and leukemia (20).

The main purpose of the present study was to investigate the incidences of respiratory and lymphatic cancers among male workers in the Norwegian pulp and paper industry, using data from a cancer register.

\section{Subjects and methods}

Various products are made in the pulp and paper industry, including newspaper, printing paper, soft paper and paperboard. The characteristics of the 11 mills included in the present study are shown in table 1 . In 9 of the mills, paper was made in the same plant as the pulp was produced. During the study period, small changes in the process were introduced, but the main features of the production were maintained.

\section{Subjects}

The present study included 23718 men who had worked continuously at $\geq 1$ of the 11 mills for at least 1 year between 1920 and 1993. Altogether 729 men (3\%) were excluded because personal identification was lacking. During the follow-up period, 6914 men died and $286 \mathrm{em}-$ igrated. The data set included name, date of birth, personal identification number, dates of entry, and termination of all employment periods and departments and job categories. A personal identification number was given to each person in Norway in 1960 and subsequently at birth or immigration. This study was restricted to include only men, because of the few number of women in the pulp-producing departments (sulfite and sulfate). Eightyfive percent of the women were employed in paper and

Table 1. Characteristics of 11 mills and processes used during different production periods in the Norwegian pulp and paper industry.

\begin{tabular}{lll}
\hline Mill number & Production period & Type of mill/process \\
\hline 1 & $1920-1993$ & Sulfite; mechanical; paper \\
2 & $1920-1993$ & Sulfite; paper \\
3 & $1920-1993$ & Mechanical; paper \\
& $1920-1991$ & Sulfite \\
4 & $1920-1993$ & Mechanical; paper \\
& $1928-1965$ & Sulfite \\
5 & $1920-1978$ & Sulfate \\
& $1956-1993$ & Paper \\
6 & $1962-1993$ & Sulfite; paper \\
7 & $1920-1978$ & Sulfite \\
& $1980-1993$ & Sulfate \\
8 & $1966-1993$ & Mechanical; paper \\
9 & $1920-1980$ & Sulfite \\
& $1980-1993$ & Sulfate \\
10 & $1920-1993$ & Paper \\
11 & $1920-1993$ & Sulfate \\
& $1920-1981$ & Sulfate \\
\hline
\end{tabular}

administration departments, and the results have been presented in a separate report (2).

\section{Methods}

Since 1953, the registration of cancers in Norway has been based on compulsory reporting of cancer cases by hospital departments and histopathological laboratories and on information on death certificates from Statistics Norway. The coding system is based on the 7 th revision of the International Classification of Diseases (ICD-7) (21). In the present study, cancers of the tongue, buccal cavity, pharynx, and larynx, corresponding to ICD-7 codes $141,143-148$ and 161 , respectively, were analyzed together.

The cohort was linked with data from the Cancer Register in order to add information on cancer diagnosis, and with data from Statistics Norway to add date of death or date of emigration. Those who died before 1960 were identified manually. The cohort was followed for cancer incidence, date of death, or emigration for the period 1953 until the end of 1993. Person-years were calculated for each man from 1 year after his first employment until death, emigration, or the end of the follow-up period, whichever came first. The person-years for each worker were cumulated for the entire follow-up period. If a man had been employed in more than 1 department, his person-years were assigned to all of the departments; 4582 men had worked in more than 1 department.

The study was based on a comparison of observed $(\mathrm{O})$ and expected (E) numbers of newly diagnosed cancer cases. The expected numbers were calculated from the 5-year age-specific incidence rates for each year for the entire male population of Norway. Standardized incidence ratios (SIR) were calculated as the ratio between the observed and expected numbers. For all the SIR values, $95 \%$ confidence intervals $(95 \% \mathrm{CI}$ ) were determined by assuming a Poisson distribution of the cancer cases. A result was regarded as statistically significant if the confidence interval did not include 1.00. The Epicure statistical package was used (22).

Analyses were performed for 2 groups: short-term workers ( $<3$ years' total employment, 4465 men, 18.8\%) and long-term workers ( $\geq 3$ years' total employment, 19253 men, 81.2\%). Separate analyses were made to investigate the possible effects of duration of employment in categories of $1-2.9$ years, $3-9.9$ years, and $\geq 10$ years. Owing to variations in exposure over time, separate analyses were performed for first exposure in 19201939, 1940-1959, 1960-1974, and 1975-1993. Separate analyses were also done according to the time since first exposure: $1-14$ years, $15-29$ years, and $\geq 30$ years.

\section{Occupational title-based approach}

The employees were divided into 6 subcohorts according to their work environment as follows: sulfite mill, 
sulfate mill, paper mill, maintenance department, administrative staff, and other departments, the last category including stock preparation, debarking and chipping, byproduction, converting, power plant and certain small departments. The administrative staff were considered to be unexposed.

The numbers of employees and person-years by department are shown in table 2. More person-years were accumulated in sulfite mills than in sulfate mills, whereas similar numbers of person-years at risk were seen in paper mills and maintenance departments; the largest number of person-years was observed in the group "other departments".

\section{Occupational exposures}

Information about different types of exposure was available for the present study. Asbestos has been used in this industry. Sulfur compounds (sulfur dioxide, sulfuric acid) were common exposures in the sulfite mills and reduced sulfur compounds (hydrogen sulfite, metylmercaptan) were present in the sulfate mills. Workers in both the sulfite and sulfate mills are exposed to chlorine compounds as a consequence of pulp bleaching. Paper dust, talc, and formaldehyde are common contaminants in paper mills, PCB are found in maintenance departments, and wood dust and microbes occur in raw wood preparation. This information was derived from responses to a detailed questionnaire filled out at each mill during participation in an international study (23). The questionnaire included questions on type of pulp and paper produced, raw materials and wood preparation, types of chemicals used, and numbers of exposed workers (24).

\section{Calculation of smoking habits}

No information on smoking habits was collected, but we used the method of Axelson (25) to estimate the effect of smoking on our cohort, by comparing the proportion of smokers in a population of wood-processing workers in Norway in 1977 (63.3\%) (26) with the proportion of smokers in the general population in Norway at the same time (50\%) (27). For both short- and long-term workers, we assumed that $80 \%$ of the smokers were moderate smokers and $20 \%$ were heavy smokers. These calculations showed that smoking habits could explain an excess risk of about $23 \%$.

\section{Results}

Altogether 594386 person-years at risk were accumulated during the follow-up period. Table 3 summarizes the incidence of cancers in the cohort in comparison with that in the national male population for short-term and long-term workers. Among the short-term workers the SIR value for cancers at all sites combined was increased
(SIR 1.3, 95\% CI 1.13-1.42), and increases were also seen for lung cancer (48 cases with 31.3 expected) and esophageal cancer ( 7 cases with 2.8 expected). Separate tabulation of the group "other specified sites" showed no excess in risk for any site included in the group. For all the other sites studied, the observed numbers were similar to those expected.

Among the long-term workers, 2282 cases of cancer at all sites were diagnosed, with 2230 expected. The risks for cancers of the lung and pleura were elevated (1.2, $95 \% \mathrm{CI} 1.09-1.34$ and $2.4,95 \% \mathrm{CI} 1.45-3.75$, respectively), and excess risks were also found for cancer of the colon and malignant melanoma. For cancers of lymphatic and hematopoietic tissues, the observed numbers were lower than expected (table 3 ).

About $50 \%$ of the cases of lung cancer occurred in the group with the longest employment and the longest latency: 183 observed cases versus 140 expected (SIR $1.3,95 \%$ CI 1.08-1.44) (table 4); however, men employed for less than 10 years had higher SIR values for lung cancer than those who had worked for $\geq 10$ years. The risk for pleural mesothelioma was also highest for men with the longest employment and the longest latency (SIR 2.8, 95\% CI 1.38-4.96). An increase in risk was also observed for workers with $3-9.9$ years of employment and $1-14$ years of latency, but on the basis of only 4 cases. The SIR values for malignant melanoma showed an increasing trend with latency, reaching significance for men with $\geq 30$ years of latency and $\geq 10$ years of employment (SIR 1.9, 95\% CI 1.33-2.51). This finding was unexpected. Separate analyses for each mill showed a higher risk for one than for the others (O 11, E 3.18, SIR 3.5, 95\% CI 1.73-6.18) (not shown in table 4). Workers employed in the period 1920-1959 had a higher risk for lung cancer than those first employed later. The SIR value for pleural mesothelioma was highest for men first employed in 1920-1939 and 1975-1993 (data not shown).

Table 2. Numbers of men employed and person-years in each department in mills of the Norwegian pulp and paper industry.

\begin{tabular}{lccc}
\hline Type of mill & $\begin{array}{c}\text { Number } \\
\text { of men }\end{array}$ & \multicolumn{2}{c}{$\begin{array}{c}\text { Person- } \\
\text { years at risk }\end{array}$} \\
\hline & & $\begin{array}{c}<3 \text { years' } \\
\text { total } \\
\text { employment }\end{array}$ & $\begin{array}{c}\geq 3 \text { years } \\
\text { total } \\
\text { employment }\end{array}$ \\
\hline Sulfite mill & 2351 & 18821 & 41078 \\
Sulfate mill & 736 & 3981 & 10676 \\
Paper mill & 7071 & 52599 & 115418 \\
Maintenance department & 5934 & 35298 & 115449 \\
Administrative department & 4894 & 38953 & 83436 \\
Other departments & 7982 & 54716 & 140090 \\
\hline Total & 28868 & 204368 & 506147 \\
\hline
\end{tabular}

The numbers of men and person-years may overlap among departments. 
Table 3. Observed (0) and expected (E) numbers of new cancer cases among short-term and long-term male workers in the Norwegian pulp and paper industry - follow-up 1953-1993. (SIR = standardized incidence ratio, $95 \% \mathrm{Cl}=95 \%$ confidence interval)

\begin{tabular}{|c|c|c|c|c|c|c|c|c|}
\hline \multirow[t]{2}{*}{ Cancer site ${ }^{a}$} & \multicolumn{4}{|c|}{ Employed $<3$ years } & \multicolumn{4}{|c|}{ Employed $\geq 3$ years } \\
\hline & 0 & $E$ & SIR & $95 \% \mathrm{Cl}$ & 0 & $E$ & SIR & $95 \% \mathrm{Cl}$ \\
\hline Lip (140) & 4 & 3.0 & 1.3 & $0.36-3.36$ & 37 & 30.4 & 1.2 & $0.86-1.68$ \\
\hline \multicolumn{9}{|l|}{ Buccal cavity, pharynx } \\
\hline and larynx $(141,143-148,161)$ & 12 & 8.1 & 1.5 & $0.77-2.60$ & 72 & 69.5 & 1.0 & $0.81-1.30$ \\
\hline Esophagus (150) & 7 & 2.8 & 2.5 & $1.00-5.12$ & 23 & 27.7 & 0.8 & $0.53-1.25$ \\
\hline Stomach (151) & 18 & 17.9 & 1.0 & $0.60-1.59$ & 173 & 195.7 & 0.9 & $0.76-1.03$ \\
\hline Colon (153) & 25 & 18.1 & 1.4 & $0.90-2.04$ & 204 & 174.9 & 1.2 & $1.02-1.34$ \\
\hline Rectum (154) & 17 & 12.3 & 1.4 & $0.81-2.21$ & 125 & 117.7 & 1.1 & $0.89-1.27$ \\
\hline Nose, sinuses etc $(160)$ & 1 & 0.8 & 1.3 & $0.03-7.23$ & 6 & 7.3 & 0.8 & $0.30-1.79$ \\
\hline Lung (162) & 48 & 31.3 & 1.5 & $1.13-2.03$ & 356 & 295.7 & 1.2 & $1.09-1.34$ \\
\hline Pleural mesothelioma (163) & 2 & 0.9 & 2.2 & $0.26-7.83$ & 19 & 7.9 & 2.4 & $1.45-3.75$ \\
\hline Prostate (177) & 32 & 33.7 & 1.0 & $0.65-1.34$ & 386 & 396 & 1.0 & $0.88-1.08$ \\
\hline Testis (178) & 9 & 8.2 & 1.1 & $0.50-2.08$ & 23 & 32.6 & 0.7 & $0.45-1.06$ \\
\hline Kidney (180) & 12 & 9.1 & 1.3 & $0.68-2.31$ & 84 & 82.5 & 1.0 & $0.81-1.26$ \\
\hline Bladder (181) & 22 & 16.0 & 1.4 & $0.86-2.08$ & 141 & 155.7 & 0.9 & $0.77-1.07$ \\
\hline Malignant melanoma (190) & 16 & 11.6 & 1.4 & $0.79-2.24$ & 88 & 67.8 & 1.3 & $1.04-1.60$ \\
\hline Other skin ${ }^{b}(191)$ & 4 & 5.9 & 0.7 & $0.18-1.73$ & 66 & 59.6 & 1.1 & $0.86-1.41$ \\
\hline Hodgkin disease (201) & 3 & 2.9 & 1.0 & $0.21-3.04$ & 15 & 17.4 & 0.9 & $0.48-1.42$ \\
\hline Non-Hodgkin lymphoma (202) & 7 & 9.7 & 0.7 & $0.29-1.48$ & 68 & 74.8 & 0.9 & $0.71-1.15$ \\
\hline Multiple myeloma (203) & 7 & 4.2 & 1.7 & $0.66-3.41$ & 37 & 43.4 & 0.9 & $0.60-1.18$ \\
\hline Leukemia (204) & 9 & 6.3 & 1.4 & $0.65-2.71$ & 53 & 58.9 & 0.9 & $0.67-1.18$ \\
\hline Other specified sites & 48 & 35.6 & 1.4 & $0.99-1.73$ & 306 & 321.7 & 1.0 & $0.86-1.07$ \\
\hline All sites (140-204) & 303 & 239.4 & 1.3 & $1.13-1.42$ & 2282 & 2230.2 & 1.0 & $0.98-1.07$ \\
\hline
\end{tabular}

a Code of the International Classification of Diseases, 7 th revision, in parentheses.

- Except basal cell-carcinomas.

Table 4. Standardized incidence ratios (SIR) with $95 \%$ confidence intervals $(95 \% \mathrm{Cl})$ for short- and long-term workers in Norwegian pulp and paper mills, by years since first exposure, years of employment, and type of cancer - follow-up 1953-1993. $(0=$ observed number of cases)

\begin{tabular}{|c|c|c|c|c|c|c|c|c|c|c|}
\hline \multirow[t]{3}{*}{ Cancer site } & \multirow{3}{*}{$\begin{array}{l}\text { Years since } \\
\text { first } \\
\text { exposure }\end{array}$} & \multicolumn{9}{|c|}{ Duration of employment } \\
\hline & & \multicolumn{3}{|c|}{$1-2.9$ years } & \multicolumn{3}{|c|}{$3-9.9$ years } & \multicolumn{3}{|c|}{$\geq 10$ years } \\
\hline & & 0 & SIR & $95 \% \mathrm{Cl}$ & 0 & SIR & $95 \% \mathrm{Cl}$ & 0 & SIR & $95 \% \mathrm{Cl}$ \\
\hline \multirow[t]{3}{*}{ Lung (162) } & $1-14$ & 5 & 0.6 & $0.18-1.32$ & 26 & 1.2 & $0.79-1.76$ & 12 & 0.9 & $0.46-1.55$ \\
\hline & $15-29$ & 21 & 1.7 & $1.02-2.52$ & 29 & 1.4 & $0.91-1.84$ & 77 & 1.1 & $0.83-1.31$ \\
\hline & $\geq 30$ & 22 & 1.8 & $1.12-2.71$ & 29 & 1.5 & $0.99-2.13$ & 183 & 1.3 & $1.08-1.44$ \\
\hline \multirow[t]{3}{*}{ Pleural mesothelioma (163) } & $1-14$ & 1 & 4.4 & $0.11-24.54$ & 4 & 7.7 & $2.10-19.74$ & 1 & 3.2 & $0.08-17.67$ \\
\hline & $15-29$ & - & & & - & & & 2 & 1.1 & $0.13-3.95$ \\
\hline & $\geq 30$ & 1 & 2.6 & $0.07-14.42$ & 1 & 1.7 & $0.04-9.35$ & $1 \overline{1}$ & 2.8 & $1.38-4.96$ \\
\hline \multirow[t]{3}{*}{ Golon (153) } & $1-14$ & 8 & 1.5 & $0.65-2.99$ & 17 & 1.4 & $0.81-2.22$ & 7 & 1.0 & $0.39-2.00$ \\
\hline & $15-29$ & 8 & 1.1 & $0.47-2.15$ & 18 & 1.4 & $0.83-2.20$ & 44 & 1.1 & $0.79-1.47$ \\
\hline & $\geq 30$ & 10 & 1.4 & $0.69-2.64$ & 16 & 1.4 & $0.81-2.31$ & 102 & 1.1 & $0.93-1.37$ \\
\hline \multirow[t]{3}{*}{ Malignant melanoma (190) } & $1-14$ & 5 & 0.9 & $0.29-2.07$ & 11 & 1.2 & $0.58-2.07$ & 2 & 0.4 & $0.05-1.42$ \\
\hline & $15-29$ & 6 & 4.2 & $0.43-2.53$ & 10 & 1.4 & $0.67-2.56$ & 20 & 1.1 & $0.66-1.68$ \\
\hline & $\geq 30$ & 5 & 2.0 & $0.64-4.60$ & 4 & 1.0 & $0.28-2.67$ & 41 & 1.9 & $1.33-2.51$ \\
\hline
\end{tabular}

a Code of the International Classification of Diseases, 7 th revision, in parentheses.

Table 5. Standardized incidence ratios (SIR) with $95 \%$ confidence intervals $(95 \% \mathrm{Cl})$ for selected types of cancer in long-term workers (employed $\geq 3$ years) in Norwegian pulp and paper mills, by department - follow-up 1953-1993. ( $0=$ observed number of cases, ICD$7=$ International Classification of Diseases, 7 th revision)

\begin{tabular}{|c|c|c|c|c|c|c|c|c|c|c|c|c|}
\hline \multirow[t]{2}{*}{ Departments } & \multicolumn{3}{|c|}{ Lung (ICD-7=162) } & \multicolumn{3}{|c|}{$\begin{array}{l}\text { Pleural mesothelioma } \\
\qquad(\mid C D-7=163)\end{array}$} & \multicolumn{3}{|c|}{ Colon (ICD-7=153) } & \multicolumn{3}{|c|}{$\begin{array}{l}\text { Malignant melanoma } \\
\quad(I C D-7=190)\end{array}$} \\
\hline & 0 & SIR & $95 \% \mathrm{Cl}$ & 0 & SIR & $95 \% \mathrm{Cl}$ & 0 & SIR & $95 \% \mathrm{Cl}$ & 0 & SIR & $95 \% \mathrm{Cl}$ \\
\hline Sulfite & 46 & 1.5 & $1.09-1.99$ & 2 & 2.4 & $0.30-8.83$ & 23 & 1.3 & $0.80-1.88$ & 10 & 1.6 & $0.78-2.97$ \\
\hline Sulfate & 12 & 1.4 & $0.73-2.47$ & 1 & 4.4 & $0.11-24.65$ & 6 & 1.2 & $0.45-2.65$ & 4 & 2.3 & $0.64-5.97$ \\
\hline Paper mill & 81 & 1.2 & $0.84-1.47$ & 3 & 1.6 & $0.33-4.68$ & 44 & 1.1 & $0.81-1.49$ & 21 & 1.3 & $0.78-1.93$ \\
\hline Maintenance & 74 & 1.2 & $0.93-1.48$ & 6 & 3.5 & $1.29-7.62$ & 42 & 1.1 & $0.82-1.54$ & 25 & 1.7 & $1.12-2.55$ \\
\hline Administrative staff & 58 & 1.1 & $0.82-1.40$ & 3 & 2.0 & $0.42-5.92$ & 30 & 1.0 & $0.65-1.37$ & 19 & 1.5 & $0.89-2.30$ \\
\hline Other departments & 123 & 1.2 & $0.97-1.38$ & 6 & 2.2 & $0.80-4.73$ & 78 & 1.2 & $0.97-1.53$ & 24 & 1.1 & $0.74-1.72$ \\
\hline
\end{tabular}


Sulfite mill workers had the highest risk for lung cancer (SIR 1.5, 95\% CI 1.09-1.99) (table 5). Maintenance workers had an increased risk for pleural mesothelioma (SIR 3.5, 95\% CI 1.29-7.62) and for malignant melanoma (SIR 1.7, 95\% CI 1.12-2.55) (table 5).

\section{Discussion}

The present study shows an excess in the risk for lung cancer, particularly among pulp production workers (sulfite and sulfate). Pleural mesothelioma was found in excess among asbestos-exposed workers. An unexpected increase in risk for malignant melanoma was found. The risk for colon cancer was also elevated but showed no trends related to risk factors.

The increased risk for lung cancer shown in the present study is in agreement with reports from other countries $(7,28,29)$. We had no information on smoking habits, but the use of Axelson's method (25) showed that smoking habits could explain a risk excess of about $23 \%$. As the increased risk for lung cancer for the entire cohort was $24 \%$ (table 3), most of the excess can be explained by smoking. Furthermore, people with less education have a $25-30 \%$ higher frequency of smoking than those with more education (27). Most of the mills included in our study are located in rural areas where the prevalence of smoking is lower than in the general population, however, and therefore the increase in lung cancer may also have been due to factors other than smoking.

The risk for lung cancer increased with increasing latency, for the total cohort (table 4). This result is in accordance with the assumption that the time for developing occupationally linked lung cancer is long. Furthermore, the risk was highest among workers first employed in 1920-1939 and 1940-1959; this finding may indicate that the work environment has changed over time. A Finnish study showed an increased risk for lung cancer among chloride-exposed workers. Even though there were few cases, the authors concluded that the excess may have been due to workplace exposure to organic chlorinated compounds (6). Earlier investigations among pulp and paper workers $(7,30)$ and wood workers (31) all concluded that the increased risk for lung cancer could not be explained by smoking alone. We observed the highest risk among sulfite mill workers, a finding in agreement with that of other reports $(3,32)$. Sulfur dioxide is a major air contaminant in sulfite mills, and nearly all process workers involved in cooking, washing, and other operations are exposed to this chemical. A working group convened by the International Agency for Research on Cancer concluded that there was inadequate evidence for the carcinogenicity of sulfur dioxide, sulfites and bisulfites in humans and experimental animals (33).
Asbestos was widely used in several departments in the pulp and paper industry. An excess in the risk for pleural mesothelioma was observed among long-term workers, as reported by others $(15,16)$. Moreover, the risk increased with increasing latency, in accordance with the time for the development of occupationally linked pleural mesothelioma. The 4 men who developed pleural cancer after a short latency may have been exposed to asbestos elsewhere. Maintenance workers had the highest risk (table 5), again a finding indicating that the excess was due to exposure to asbestos. All of the men in "other departments" had jobs that could have involved asbestos exposure. The cases among administrative workers must have been due to exposure outside this industry.

Our study does not support the finding by other authors (17-20) of an increased risk for lymphatic cancers or leukemia. It has been suggested that exposure to fresh wood is a probable risk factor for malignant lymphoma (1).

The increase in the incidence of malignant melanoma of the skin observed by us was an unexpected finding. The strongest risk factor for this cancer is considered to be solar radiation (34). Geographic differences in the incidence of malignant melanomas in Norway are essential, and further analysis of our data showed an excess risk for men in one particular mill located in the southern part of Norway (data not shown), an area that also has the highest incidence of this disease in Norway (35). Regional differences in ultraviolet radiation could therefore explain most of the risk in our study.

In a study of the relationships between various occupational exposures and the risk for malignant melanoma of the skin in the United States, some exposures occurring in the pulp and paper industry were included (asbestos, dyes, formaldehyde, wood dust, and diesel engine exhaust), but none seemed to increase the risk (36). Another study showed no substantial excess of malignant melanoma among cellulose plant and paper workers (37). Table 4 of our report shows a clear trend in risk with latency and duration of work (the SIR rising from 0.4 to 1.9). These data indicate that occupational exposure might have been involved in causing these tumors. One occupational exposure that has been related to melanoma of the skin is PCB (38), and PCB are used in capacitors and transformers. The risk for malignant melanoma was highest among maintenance workers, who are known to handle PCB while repairing PCB-containing equipment or removing these agents. In an international study of occupational exposures in the nonproduction departments of the pulp and paper industry, to which the mills in the present study contributed, PCB were considered to be a noteworthy exposure of maintenance personnel, especially electricians servicing capacitors and transformers (39).

Scand J Work Environ Health 2000, vol 26, no 2 
The current investigation included more than 500000 person-years and is the largest occupational cohort ever studied in Norway. Company record files of high quality and consistency over the study period, made it possible to describe specific department and job categories for each worker. As much as $81.2 \%$ of the workers had been employed for more than 3 years, and therefore the work force was evidently relatively stable, only $3 \%$ of the workers not being identified.

The increased risk for lung cancer is in agreement with the findings of other studies among pulp and paper workers and may be explained by a combination of smoking habits, asbestos use and other work-related exposures, and the increased risk for pleural mesothelioma is linked to the use of asbestos. We have no clear explanation for the excess risk for malignant melanoma. Although exposure to PCB occurs in this industry and has been suggested as a risk factor for this malignancy, the excess risk may be a chance finding

\section{Acknowledgments}

This work was supported by a grant from the Work Environment Fund of the Confederation of Norwegian Business and Industry, The Norwegian Cancer Society and the Pulp and Paper Industry. Thanks are given to the Confederation of Norwegian Process Industry and to the committee members of the project. We also express our gratitude to our colleagues at the Cancer Registry of Norway for their assistance.

\section{References}

1. Torén K, Persson B, Wingren G. Health effects of working in pulp and paper mills: malignant diseases. Am J Ind Med 1996;29:123-30.

2. Langseth $\mathrm{H}$, Andersen A. Cancer incidence among women in the Norwegian pulp and paper industry. Am J Ind Med 1999;36:108-13.

3. Rix BA, Villadsen E, Lynge E. Cancer incidence of sulfite pulp workers in Denmark [short communications]. Scand J Work Environ Health 1997;23:458-61.

4. Andersson E, Nilsson T, Persson B, Wingren G, Torén K. Mortality from asthma and cancer among sulfite mill workers. Scand J Work Environ Health 1998;24:12-7.

5. Matanoski GM, Kanchanaraksa S, Lees PSJ, Tao Xu-Guang, Royall R, Francis M, et al. Industry-wide study of mortality of pulp and paper mill workers. Am J Ind Med 1998;33:354_65.

6. Jäppinen P, Pukkala E. Cancer incidence among pulp and paper workers exposed to organic chlorinated compounds formed during chlorine pulp bleaching [shorter communications]. Scand J Work Environ Health 1991;17:356-9.

7. Jäppinen P, Hakulinen T, Pukkala E, Tola S, Kurppa K.
Cancer incidence of workers in the Finnish pulp and paper industry. Scand J Work Environ Health 1987;13:197-202.

8. Torén K, Sällsten G, Järvholm B. Mortality from asthma, chronic obstructive pulmonary disease, respiratory system cancer, and stomach cancer among paper mill workers: a casereferent study. Am J Ind Med 1991;19:729-37.

9. Siemiatycki J, Richardson L, Gérin M, Goldberg M, Dewar R, Désy $M$, et al. Associations between several sites of cancer and nine organic dusts: results from an hypothesis-generating case-control study in Montreal, 1979-1983. Am J Epidemiol 1986;123:235-49.

10. Robinson CF, Waxweiler RJ, Fowler DP. Mortality among production workers in pulp and paper mills. Scand J Work Environ Health 1986;12:552-60.

11. Coggon D, Wield G, Pannett B, Campbell L, Boffetta P. Mortality in employees of a Scottish paper mill. Am J Ind Med 1997;32:535-9.

12. Szadkowska-Stañczyk I, Boffetta P, Wilczyñska U, Szeszenia-Dabrowska N, Szymczak W. Cancer mortality among pulp and paper workers in Poland: a cohort study. Int J Occup Med Environ Health 1997;10:19-29.

13. Wong $\mathrm{O}$, Ragland $\mathrm{DR}$, Marcero DH. An epidemiologic study of employees at seven pulp and paper mills. Int Arch Occup Environ Health 1996:68:498-507.

14. Sala-Serra M, Sunyer $J$, Kogevinas M, McFarlane D, Antó JM. Cohort study on cancer mortality among workers in the pulp and paper industry in Catalonia, Spain. Am J Ind Med 1996;30:87-92.

15. Malker HSR, McLaughlin JK, Malker BK, Stone BJ, Weiner JA, Erickson JLE, et al. Occupational risks for pleural mesothelioma in Sweden, 1961-79. JNCI 1985;74:61-6.

16. Band PR, Le ND, Fang R, Threlfall WJ, Astrakianakis G, Anderson JTL, et al. Cohort mortality study of pulp and paper mill workers in British Columbia, Canada. Am J Epidemiol 1997; 146:186-94.

17. Milham S Jr, Demers RY. Mortality among pulp and paper workers. J Occup Med 1984;26:844—6.

18. Svirchev LM, Gallagher RP, Band PR, Threlfall WJ, Spinelli JJ. Gastric cancer and lymphosarcoma among wood and pulp workers [letter]. J Occup Med 1986;28:264-5.

19. Milham S Jr. Neoplasia in the wood and pulp industry. Ann NY Acad Sci 1976;271:294-300.

20. Schwartz E. A proportionate mortality ratio analysis of pulp and paper mill workers in New Hampshire. Br J Ind Med $1988 ; 45: 234-8$

21. World Health Organization (WHO). International classification of diseases, 7th revision. Geneva: WHO, 1957.

22. Preston DL, Lubin JH, Pierce DA, McConney ME. Epicure. Seattle (WA): Hirosoft International Corporation, 1993.

23. Boffetta $P$, Kogevinas M, Saracci R, Vainio H. International cohort study on cancer risk among workers in the pulp and paper industry: protocol of the study. Lyon: International Agency for Research on Cancer, 1991.

24. International Agency for Research on Cancer (IARC). Mill questionnaire for the IARC international epidemiological study of workers in the pulp and paper industry. Lyon: IARC, 1992.

25. Axelson O. Aspects on confounding in occupational health epidemiology [letter to the editor]. Scand J Work Environ Health 1978;4:98-102.

26. Natvig $H$. Røykevanene hos ansatte i bedrifter med bedriftshelsetjeneste [Smoking habits among employees in firms with a health service]. Tidsskrift Nor Lægeforen 1977; 27:1376-80. 
27. Norwegian Council on Tobacco and Health. Tobakksbruk og holdninger i Norge - utviklingen 1973-95 [Use of tobacco and attitude in Norway - trends 1973-95]. Oslo: Norway, 1996.

28. Menck HR, Henderson BE. Occupational differences in rates of lung cancer. J Occup Med 1976;18:797_801.

29. Solet D, Zoloth SR, Sullivan C, Jewett J, Michaels DM. Patterns of mortality in pulp and paper workers. J Occup Med $1989: 31: 627-30$.

30. Jäppinen $P$, Tola $S$. Smoking among Finnish pulp and paper workers - evaluation of its confounding effect on lung cancer and coronary heart disease rates. Scand J Work Environ Health 1986;12:619-26.

31. Stellman SD, Garfinkel L. Cancer mortality among woodworkers. Am J Ind Med 1984;5:343—57.

32. Henneberger PK, Ferries BG Jr, Monson RR. Mortality among pulp and paper workers in Berlin, New Hampshire. Br J Ind Med 1989;46:658-64.

33. International Agency for Research on Cancer (IARC). Occupational exposures to mists and vapours from strong inorganic acids; and other industrial chemicals. Lyon; IARC, 1992. IARC monographs on the evaluation of carcinogenic risks to humans, vol 54.

34. Winther JF, Ulbak K, Dreyer L, Pukkala E, Østerlind A. Radiation. Acta Pathol Microbiol Immunol Scand 1997;105 suppl 76:83-99.

35. Cancer Registry of Norway. Cancer in Norway 1995. Oslo: Cancer Registry of Norway, 1995.

36. Pion IA, Rigel DS, Garfinkel L, Silverman MK, Kopf AW. Occupation and the risk of malignant melanoma. Cancer 1995;75 suppl 2:637-44.

37. Linet MS, Malker HSR, Chow W-H, McLaughlin JK, Weiner JA, Stone BJ, et al. Occupational risks for cutaneous melanoma among men in Sweden. J Occup Environ Med 1995;37:1127-35

38. Ward EM, Burnett CA, Ruder A, Davis-King K. Industries and cancer. Cancer Causes Control 1997;8:356-70.

39. Teschke K, Ahrens W, Andersen Aa, Boffetta P, Fincham S, Finkelstein $M$, et al. Occupational exposure to chemical and biological agents in the nonproduction departments of pulp, paper and paper product mills: an international study. Am Ind Hyg Assoc J 1999;60:73-83.

Received for publication: 11 May 1999 